\title{
Research on Chinese Listed Companies' Financial Fraud
}

\author{
Xiaoyong Lu \\ Nanchang University \\ Nanchang, China \\ 1xy@ncu.edu.cn
}

\begin{abstract}
Listed company's financial fraud is not only the investors' interests having been infringed and lost confidence in the investment, also make the credibility of the accountant be questioned and disrupt the normal social and economic order. This article summarizes the commonly used means of forgery of the listed companies, which made the governance of financial fraud countermeasures.
\end{abstract}

Keywords-listed companies; financial fraud common means; measures

\section{I . INTRODUCTION}

In recent years, it has been exposed a number of large listed companies making false accounts for financial fraud to deceive the majority of investors scandal.

Since the 2012 semi-annual report false records and material omissions, the Shenzhen Stock Exchange decided to give the public reprimand sanction for Wan fu sheng ke, including the chairman of the company and related personnel. Wan fu sheng ke said in an announcement released on October 26, 2012, the corporation inflated operating income 188 million yuan, 146 million in yuan flated operating costs, and inflated profits 40,231,600 yuan.

Of Chinese capital market is in a period of development, and the capital operation is not yet mature, the listed financial fraud issues is even more prominent. In the capital market financial fraud cases are widespread and repeated. From an economic point of view of social wealth, financial fraud is an unfair transfer of wealth in society means that it is against the majority of people, especially the country's interests to achieve the minority interests. Financial fraud is a serious waste behavior, it makes a lot of socio-economic scarce resources drained away, and the effects are even worse that the behavior disrupts the normal capital market financing. Such dishonesty will make social economy into a vicious cycle and can not get out. Financial fraud is a failure behavior of capital market financing, it will not only obstacles to social and economic development but also on creating more jobs causing considerable negative effect. Therefore, finding the listed companies' financial fraud causes and exploring both temporary and permanent solution of a financial fraud prevention road is worthy of attention and exceptionally difficult task placed in front of a national scholar.

\author{
Jing $\mathrm{Xu} *$ \\ Nanchang University \\ Nanchang, China \\ 1074016780@qq.com
}

\section{II . FINANCIAL FRAUD AFFECTING OF LISTED COMPANIES}

Listed company financial fraud is a serious departure from the rules of market economy behavior. The company's survival and development is inseparable from capital and market, the financial information provided by the listed companies on the open market is a very important reference to the public's understanding of company performance. Listed company publish their financial information, external user, including shareholders, creditors, pot ential investors and other social public, will be based on the financial information reflected information to make their own decisions. Accordingly, the financial information of listed companies is directly related to fraud a serious departure from the rules of market economy behavior. It will not only seriously undermine the financial information for decision-usefulness, serious violations of the general interests of creditors and investors, making the community on the basis of accounting integrity doubt, will fundamentally undermine the market economy in the basis of credit, distort and weaken the capital raising equity capital markets capabilities and resource allocation functions, endanger the normal operation of the national economy. Financial information frauds the same time also contributing to breed corruption, a serious impediment to economic and social development and the company's health reform carried out smoothly.

\section{COMMON MEANS OF LISTED COMPANIES' FINANCIAL FRAUD}

As essentially and deliberately providing a misleading financial reporting behavior, listed companies' financial fraud means include: fictitious transactions to manipulate profits, abusing of related party transactions, false recognition of revenues and expenses, adjusting the proportion of equity investments, concealmenting or disguising major economic issues, losing virtual assets, abusing impairment provision capitalizing interest expense and so on.

\section{A. For Fictitious Transactions and Manipulating Profits}

The most common means of listed companies' financial fraud to whitewash financial statements is fictitious economic business, which includes fictitious sales targets, forging purchase and sale contracts, falsifing export declarations, filling out false invoices and Delivery, confusing accounts.

ST Jiantong, a subsidiary of Beijing China Network Technology Services Ltd. inflated operating income, inflated 
profits, leading to its listed companies in 2007 annual profit of 17.1581 million 2011 Hunan Tian run Chemical Development Co.Ltd. exists accounting documents missing, account does other issues, Fictional sales income 81.31 million yuan. 2011 Yunnan Green Land suspected of financial fraud. From 2004 to 2007 June, Green Land companies use false contracts, financial information, inflated 960 acres of barren hills jiuxian the right to use in Malong County village, Yunnan Province, Marlon County Maming township 3500 acres of barren hills and Maming Ji land use rights fences, irrigation systems, soil improvement works projects such as Total assets 70,114,000 yuan.

In 2011, Zixin Pharmaceutical suspected fraudulent transactions to be critically. The company achieved revenues of 640 million yuan in 2010, an increase of $151 \%$, net profit of 173 million yuan, an increase of $184 \%$.

First half of 2011, revenues of 370 million yuan, net profit 111 million yuan, an increase of $226 \%$ and $325 \%$, but these figures are its "from buying from selling" the creation of shell companies set up. According Zi Xin Pharmaceutical report shows that in 2009 former five Customer cumulative purchase amount less than 27 million yuan (Table I), accounting for $10 \%$ of revenues. By the 2010, purple Xin Pharmaceutical former 5 customers purchase amount of 230 million yuan of total revenue (Table II), accounting for $36 \%$. This mysterious five largest customers after investigation, ultimately point directly to $\mathrm{Zi}$ Xin Pharmaceutical the actual controller Chunsheng or his family, Some companies are registered with its "shell company". Through which shell companies "from buying from selling", to fabricate transactions, which inflated profits, staged a magnificent large cattle market.

\section{B. Abuse of Related Party Transactions}

Associated transactions mainly consist of parent and subsidiary inventory _ purchase and sales, purchase and sale of assets, asset replacement, exchange of funds between entrusted with the operation of various cost-sharing. Due to the defects of corporate governance structure, making the holding company can be freely make therelated party transactions between the companies left and right. Management of listed companies often make use of these related party transactionstions to achieve conceal huge losses and inflated operating profit purposes, the same time, in its financial statements and the notes are not associated with to these related party transactions as well as true, full and proper disclosure. Associated the purchase and sale fraud, entrusted with the operation fraud, money exchanges fraud and other cost-sharing is important part of improper related party transactions.

Founded in March 2001, Yunnan Green Land Biological Technology Co. Ltd. During 2004 to 2009, in the absence of an initial public offering and listing of conditions, to achieve the purpose of the Listing, after the the complicity and planning of the company executives Xuekui, Jiang Casey, Pang Mingxing, its employees Zhao Haili, Zhao Haiyan register a group of companies which are actual controlled or mastered bank account affiliated companies by Green Land, and use the relevant bank accounts controlled flow of funds in the Green Land many downstream companies, most of which are affiliated companies, mostly around people registered Xuekui. These companies false contracts signed with Green Land, to do high revenues and profits, packing a "pretty" reports. Furthermore, in 2010 in Shenzhen Accord Pharmaceutical Co. Ltd. on the disclosure of related party transactions and balances are not real 109 million yuan, is not disclosed to related parties 150 million yuan credit contract guarantees.

\section{False Recognition of Revenues and Expenses}

According to Revenue recognition provided requires a corresponding adjustment of the time and cost of carry, is a commonly method of whitewash on financial statements used by a listed company. Access to Information show Kodak shares exist the behavior of the date of the transaction in April 2006 to April 2008 be altered, and after this the subsequent disclosure of information is still carried out false, and blinded investors continuously four fiscal years.

Qinghai Chen Tai Real Estate Development Co. Ltd. In 2011 in the development of the real estate has not yet completed meet the salable condition, taking early recognition of revenue 500 million YUAN and 251 million YUAN to inflated long-term investments. In 2009, AVIC Huiteng Wind Power Equipment Co. issued by the internal storehouse as the basis of the 108 units delivered to customers which are not yet recognized revenue $113,720,000$ yuan blade, and multi-account current profit 29.4 million yuan, more than total sales income of 113 million yuan.

In 2011, from the the Ministry of Finance issued Accounting information display that Guizhou Yi Bai pharmaceutical Co. Ltd. make sales revenue of 14.16 million yuan in 2008 pastpone accounted in 2009, and put the sales revenue 17,300,000 yuan in 2009 postponed accounted in 2010. These are false revenue recognition, expense performance.

\section{Adjusting the Proportion of Equity Investments}

Beganning in 2007, the new "Accounting Standards" provides, long-term equity investment accounting method is determined by its stake, it consists of cost method and equity method. If adopting the equity method of accounting, whether subsidiary is a surplus or loss, the parent company must be recognized in accordance with its own stake investment gains or losses. If the cost method, parent company does not make the accounting treatment even subsidiary gets net profi ,but when a subsidiary distribution of profits or cash dividends declared, the parent company would recognize current investment income. For severe loss of subsidiary, Listed companies always cut a large number of holdings of shares so that less than $20 \%$ stake in accounting period, in order to achieve a short time to avoid investment losses and to increase profits. For those subsidiaries that expect a profit, listed companies often falsely raise its stake above $20 \%$,in order to significantly increase its investment returns.

Qinghai tripod 2010 annual report shows, in the top ten shareholders of the table, Qinghai Fengzhen Technology Investment Co. Ltd. Qinghai Tianxiang Investment Industrial Ltd. and Qinghai Siwei Credit Guarantee Co., Ltd. with the second to fourth place. Each holds stake is $12.58 \%, 9.82 \%$ and 4.98\%.While 2011 semi-annual report, with successive holdings of shares, Qinghai Fengzhen Technology Investment 
Co., Ltd.and Qinghai Siwei Credit Guarantee Co. are out of the top ten shareholders of the table, only leaving Tianxiang remaining investment to $4.27 \%$ stake, ranked the second largest shareholder. It is noteworthy that 2011 semi-annual report shows that Qinghai Tianxiang Investment Industrial Ltd. Holdsc101,200,000 tradable shares. While Third Quarterly Report shows it holds 3,000,000 tradable shares.

Since reduction of too anxious, Qinghai tripod the condition that $t$ even faster does not wash mud radish. In the March 21 evening, due to the shareholders Fengzhen Technology reduction of ratio reached Qinghai tripod 5\% of the total shares traded failure to stop and fulfill statutory disclosure obligation in October 27, 2010 to 201121 January daytime. The company was publicly condemned by the Shanghai Stock Exchange, and punished that keep it in integrity records of listed companies. From all sides, the information can be seen that, since from October 2010, the three shareholders nearly accumulated cash 700 million yuan.

\section{IV . GOVERNANCE OF LISTED COMPANIES' FINANCIAL FRAUD MEASURES}

\section{A. Improve Governance Structure of the Company}

Improve the corporate governance structure of the company's management can strengthen and improve the Company's operating results, to improve the quality of financial statements, from the source to curb the incidence of financial fraud. Improve the corporate governance structure from the following aspects: first, Optimized listing shareholding structure, second, perfect board of supervisors system, third, perfect independent Director System, the last one building manager market and reputation mechanisms

\section{B. To Maintain the Independence of CPA Audit}

The essential feature of audit is independence, lack of independence there is no audit. To maintain the independence of the audit CPA multi-pronged approach we should. At first, Strengthen our CPA of variational management should establish variational management of listed companies and their auditors CPA disclosure regime requires listed companies to fully and timely disclosure of accounting firms and their auditors to change matters for investors make a reasonable and accurate decision-making information. Then, strengthen professional ethics education

\section{Strict Law Enforcement and Increase Penalties}

To curb the listed company's financial fraud effectively must learn from the American government financial scandal remediation measures, that is increasing the crackdown of financial fraud.

\section{Strengthen the Integrity of the System Construction}

We should strengthen the construction of ideological and moral within the whole society, to keep honesty and trustworthiness, to build a strong social media guidance and supervision system and strengthen the integrity and moral force, Adhere to the "honest and trustworthy, to unscrupulous ashamed," the socialist concept of honor to create the good faith and harmonious social environment.

\section{REFERENCES}

[1] Chen Xiangxi Listed Companies in China financial fraud Causes and Countermeasures $[\mathrm{J}]$. Chongqing Industry Vocational and Technical College, 2011, (22) :84-86

[2] Wu Peng. On the listed company's financial fraud [J]. Economics and Management, 2009, (1) : 73-74

[3] Zhang Jing. Governance structure of listed companies [N] Analysis of Gansu Lianhe University, 2011, (4) :26-28

[4] Renhai Song. Financial Reporting fraud in the micro factors [J]. Liaoning Economy, 2007, (7): 70

[5] Ge Hailin. Discussion false financial reports of listed companies of prevention. Southern economy, 2003, (8)

[6] Ping Gaofei. U.S. listed companies financial fraud and corporate governance: an overview [J]. Contemporary economic, 2008, (8): $146-147$ 